\title{
An Experimental Investigation on FaL-G Paste
}

\author{
Niranjan PS ${ }^{1}$, Radhakrishna ${ }^{2}$ \\ Professor and Head, Dept of Civil Engineering, NEW HORIZON College of Engineering, Bangalore ${ }^{1}$ \\ Associate Professor and Dean, Civil Engineering, R V College of Engineering Bangalore ${ }^{2}$
}

\begin{abstract}
FaL-G is the product name given to a cementitious mixture composed of Fly ash (Fa), Lime (L) and Gypsum (G). It is low-cost and environmental-friendly material very useful in rural housing industry. Since it is manufactured using industrial wastes and by-products, the environmental impacts are mitigated. This paper addresses the technology of making compressed FaL-G paste blocks with low-calcium (Class F) dry fly ash procured from Raichur Thermal Power Plant, Karnataka and sponge iron plant Malur. The cardinal aim is to study the setting and strength characteristics of FaL-G paste. Its applicability as controlled low strength material is also ascertained. The FaL-G paste compressed cylinders were prepared without the use of conventional cement. The compressive strength of FaL-G cylinders were tested with different parameters. It was noticed that the strength of FaL-G paste increases with age and adequate to use it in making deferent composites. FaL-G paste can also be used as controlled low strength material as it has good relative flow area and adequate strength development with age.
\end{abstract}

Keywords: fly ash, lime, Gypsum, paste, CLSM, compressive strength.

\section{INTRODUCTION}

In recent times the emission of carbon dioxide into the air is being increased day by day due to various reasons. This weakens the heat-trapping blanket that surrounds the planet, causing global warming.

Various alternatives can be considered to protect the planet. The rapid increase in the capacity of thermal power generation has resulted in the production of a huge quantity of fly ash. The prevailing disposal methods are not free from environmental pollution and ecological imbalance.

On the other hand, the production of each ton of cement releases an equal amount of carbon dioxide to the atmosphere. The usage of cement can be reduced by using the other possible cementing materials without compromising the strength and durability.

The most basic building material for construction of houses are the usual burnt clay bricks and concrete blcoks. A significant quantity of fuel is utilized in making the bricks. Also, continuous removal of topsoil, in producing conventional bricks creates environmental problems. Cement concrete blocks need conventional cement and not a sustainable material.

There is strong need to adopt cost effective sustainable technologies using local materials and appropriate/intermediate technologies using materials with efficient and effective technology inputs. Different methods are adopted to produce the building blocks using cement, lime-fly ash, lime-slag bindings etc. There is a need to develop simple and highly effective technologies for producing the building blocks.

This is in considering the short supply, increasing cost, energy and environment considerations for traditional and conventional materials. The possibility of using innovative building materials and technologies, using waste material like fly ash has been considered. There is a need to adopt cost-effective and environmentally appropriate technologies by upgrading of traditional technologies, as also using local materials. Building materials is an area where enormous amount of innovation for cost reduction can be achieved.

FaL-G is the product name given to a cementitious mixture composed of Fly ash (Fa), Lime (L) and Gypsum (G). It is low-cost and environmental-friendly material very useful even in rural housing industry. FaL-G in certain proportions, as a building material, is an outcome of innovation to promote large-scale utilization of fly ash by Bhanumathidas and Kalidas [1]. It gains strength like any other hydraulic cement, in the presence of water, and is water resistant when hardened.

Large amounts of gypsum and fly ash are available at phosphoric acid manufacturing plants and thermal power plants, respectively. These materials can be used to source sulphate and silica alumina. Gypsum contains impurities of phosphate, fluoride, organic matter and alkalies which prevent its direct use as building material. It is one of the calcium sulphate's rich residues. Phosphogypsum is an important by-product of phosphoric acid fertilizer industry.

It consists of $\mathrm{CaSO}_{4} \cdot 2 \mathrm{H}_{2} \mathrm{O}$ and contains some impurities such as phosphate, fluoride, organic matter and alkalies. Approximately 5 million tons of phosphogypsum is produced each year in India [2]. Cementitious binder, FaL$\mathrm{G}$, finds extensive application in the manufacturing of building components and materials such as bricks, hollow bricks and structural concretes. FaL-G technology enables production of bricks with a simple process of mixing and water curing.

Due to such appropriate technology apart from economy, conservation of energy and pollution control are also 
achieved [3]. The FaL-G specimens like 50:40:10(flyash:lime:gypsum) with different combination were casted and air dried. The samples were kept for curing under the condition of room temperature. The specimens are cured for 7, 28, 56 and 90 days. The FaL-G material can also be recommended as CLSM i.e., controlled low strength material.

The range of RFA (relative flow area) and Strength development is quite considerable implying that number of trials would be involved in arriving suitable combinations. Since the strength development is influenced by several factors such as type of fly ash, lime, age and characteristics of materials.

FaL-G technology contributes to the conservation of energy and reduces environmental degradation. Since it is manufactured using industrial wastes and by-products of industry, the environmental impacts are mitigated. FaL-G plants have the advantage of continuous year-wide operation and hence provide year-long employment opportunity to skilled artisans.

It creates self-help livelihood opportunities for the people. In certain cases, where by-product lime is not available in adequate quantity, ordinary Portland cement is used as the source of lime, producing the same quality of bricks and blocks.

\section{Scope of research}

FaL-G is relatively economical material derived from base materials like fly ash, lime and gypsum. The research reported till date speaks about the random use of the material without any rational approach. The report on proportioning, strength development in FaL-G paste is very less.

This forms the basic of any FaL-G product. Also there is large scope for the development of FaL-G compressed blocks made from mortar. In this paper the study of physical, chemical, setting characteristics and compressive strength of different proportions of FaL-G paste at different ages are studied. The suitability FaL-G as controlled low strength material is also examined.

\section{Materials and Methods}

Dry fly ash was procured from Raichur Thermal Power Plant Karnataka (FA1)and sponge iron plant Malur (FA2) The processed fly ash (FA3) used was procured from DIRK company, Nasik. Two different limes were used in the research viz lime Slaked lime(L1) and Readymade lime(L2).

The physical and chemical properties of fly ashes used in this investigation are indicated in Tables $\mathbf{1}$ and 2.Chemical properties of slaked lime, commercially available lime and gypsum are indicated in Tables 4,5 and 6.

The chemical composition of fly ash samples FA1 and FA3 are almost same except the particle size. Whereas the sample FA2 is significantly different as the source is different. The major change in the composition is in $\mathrm{Al}_{2} \mathrm{O} 3$ and $\mathrm{SiO}_{2}$. The ratio of $\mathrm{SiO}_{2}$ and $\mathrm{Al}_{2} \mathrm{O}_{3}$ of the ashes FA1, and FA3 is around 2 suitable to use for making low $\mathrm{CO}_{2}$ cements, These fly ash samples satisfy the requirements of IS: 3812[172].

The ash sample FA2 was particularly used to study the impact of chemical and physical composition on the properties of FaL-G paste.

There is variation in the specific gravity and grain size distribution of the ashes. The fly ash FA1 is finer compared to other two types of ashes as there are no particles less than 45 microns.

This can also be confirmed by SEM images as in Figs 1,3 and 5. SEM images of the ash indicate that almost all the particles in fly ash are spherical and smooth. The $\mathrm{X}$ - ray diffraction (XRD) spectra showed that all the fly ash samples have large diffuse peak at about $20-40^{\circ}\left(2 \theta_{\max }\right)$ as indicated in Figs 2,4and 6. The study confirms the presence of crystalline phases of Quartz and Mullite in matrix of alumino silicate glass.

Table 1 Chemical Properties of fly ash

\begin{tabular}{|c|c|c|c|c|c|c|c|c|}
\hline \multirow{2}{*}{ Binder } & \multicolumn{7}{|c|}{ Chemical Composition in percentage } \\
\cline { 2 - 10 } & $\mathrm{Al}_{2} \mathrm{O}_{3}$ & $\mathrm{Fe}_{2} \mathrm{O}_{3}$ & $\mathrm{SiO}_{2}$ & $\mathrm{MgO}$ & $\mathrm{SO}_{3}$ & $\mathrm{Na}_{2} \mathrm{O}$ & Total Chlorides & $\mathrm{CaO}$ \\
\hline $\mathrm{FA} 1$ & 31.36 & 1.5 & 61.25 & 0.75 & 0.53 & 1.35 & 0.06 & 3.20 \\
\hline $\mathrm{FA} 2$ & 57.14 & 2.1 & 37.14 & 1.66 & 0.4 & 1.2 & 0.056 & 0.3 \\
\hline FA3 & 30.531 & 3.91 & 59.51 & 1.96 & 1.091 & 1.211 & 0.039 & 1.74 \\
\hline
\end{tabular}

Table 2 Physical Properties of fly ash

\begin{tabular}{|c|c|c|c|c|c|}
\hline Binder & $\begin{array}{c}\text { Specific } \\
\text { Gravity }\end{array}$ & $\begin{array}{c}\text { Percentage } \\
\text { Finer than } \mathbf{4 5} \boldsymbol{\mu}\end{array}$ & $\begin{array}{c}\text { Fineness, } \\
\mathbf{m}^{\mathbf{2}} \mathbf{K} \mathbf{K}\end{array}$ & $\begin{array}{c}\text { Loss on } \\
\text { Ignition }\end{array}$ & $\begin{array}{c}\text { Lime reactivity, } \\
\mathbf{M p a}\end{array}$ \\
\hline FA1 & 2.40 & 0.00 & 1134.1 & 0.9 & 7.23 \\
\hline FA2 & 2.55 & 2.46 & 356 & 22.85 & 4.7 \\
\hline FA3 & 2.40 & 16.12 & 350 & 1.2 & 5.4 \\
\hline
\end{tabular}


International Advanced Research Journal in Science, Engineering and Technology Vol. 2, Issue 3, March 2015

\begin{tabular}{|c|c|c|c|c|c|c|c|}
\hline Specific Gravity & \multicolumn{7}{|c|}{ Chemical Composition in percentage } \\
\cline { 2 - 7 } & $\mathrm{Al}_{2} \mathrm{O}_{3}$ & $\mathrm{Fe}_{2} \mathrm{O}_{3}$ & $\mathrm{SiO}_{2}$ & $\mathrm{MgO}$ & $\mathrm{SO}_{3}$ & $\mathrm{Na}_{2} \mathrm{O}$ & $\mathrm{CaO}$ \\
\hline 2.83 & 0.56 & 0.2 & 1.23 & 3.71 & --- & ----- & 94.3 \\
\hline
\end{tabular}

Table 4 Chemical properties of Readymade lime (L2)

\begin{tabular}{|c|c|c|c|c|c|c|c|c|}
\hline \multirow{2}{*}{$\begin{array}{c}\text { Specific } \\
\text { Gravity }\end{array}$} & \multicolumn{7}{|c|}{ Chemical Composition in percentage } \\
\cline { 2 - 9 } & $\mathrm{Al}_{2} \mathrm{O}_{3}$ & $\mathrm{Fe}_{2} \mathrm{O}_{3}$ & $\mathrm{SiO}_{2}$ & $\mathrm{MgO}$ & $\mathrm{SO}_{3}$ & $\begin{array}{c}\text { Acid } \\
\text { insoluble } \\
\text { ash }\end{array}$ & $\begin{array}{c}\text { Other } \\
\text { acid }\end{array}$ & $\mathrm{CaO}$ \\
\hline 2.77 & 0.87 & 0.56 & 2.79 & --- & --- & 5.89 & 4.41 & 85.48 \\
\hline
\end{tabular}

Table 5 Chemical properties of Gypsum

\begin{tabular}{|c|c|c|c|c|c|}
\hline \multirow{2}{*}{$\begin{array}{l}\text { Specific } \\
\text { Gravity }\end{array}$} & \multicolumn{5}{|c|}{ Chemical Composition in percentage } \\
\cline { 2 - 6 } & $\mathrm{Al}_{2} \mathrm{O}_{3}$ & $\mathrm{Fe}_{2} \mathrm{O}_{3}$ & $\mathrm{SO}_{3}$ & $\mathrm{Na}_{2} \mathrm{O}$ & Other chemical \\
\hline 2.3 & 0.56 & 0.05 & 69.73 & 1.59 & 41.9 \\
\hline
\end{tabular}

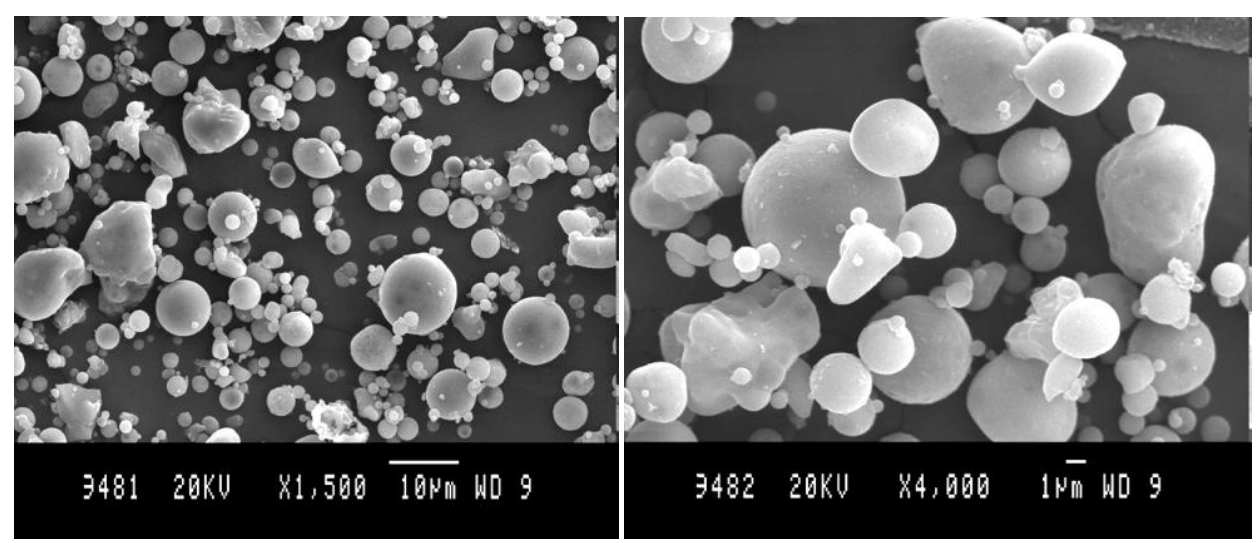

Magnification 10um

Magnification 1um

Fig 1. SEM images of Fly Ash - FA1

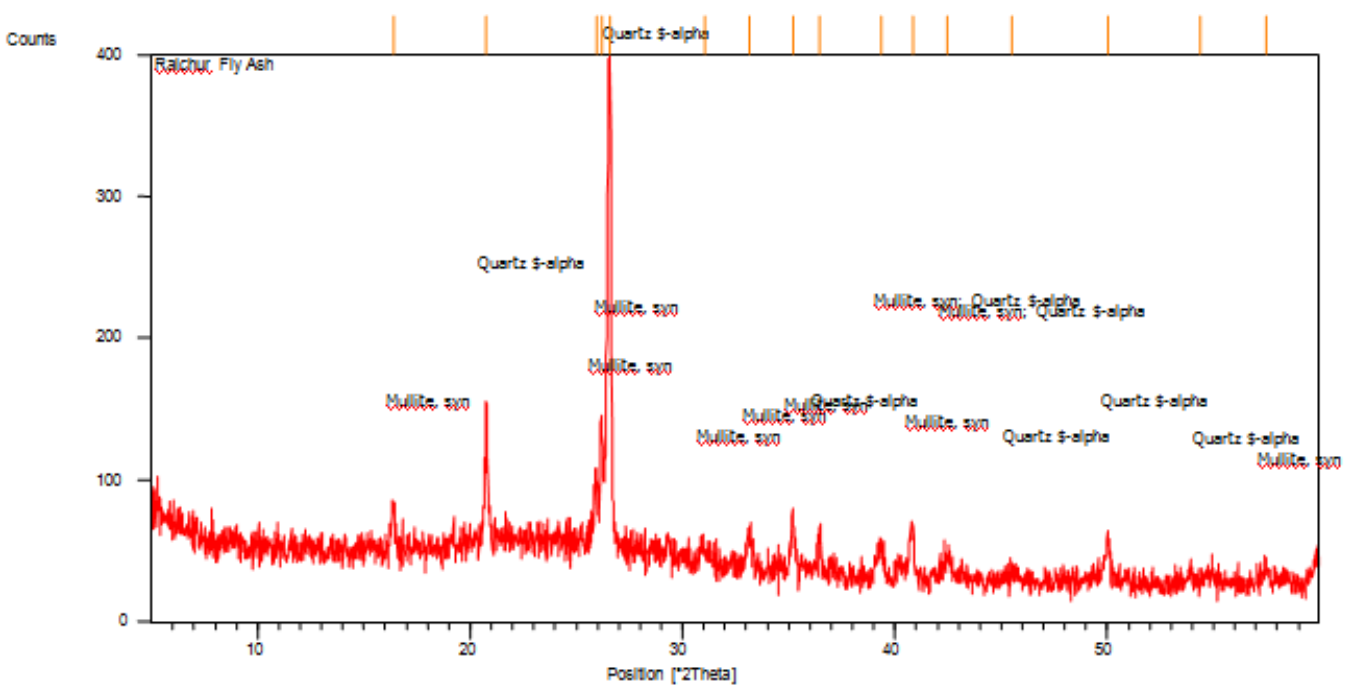

Fig2. X- Ray Diffractogram of fly ash - FA1 
International Advanced Research Journal in Science, Engineering and Technology Vol. 2, Issue 3, March 2015

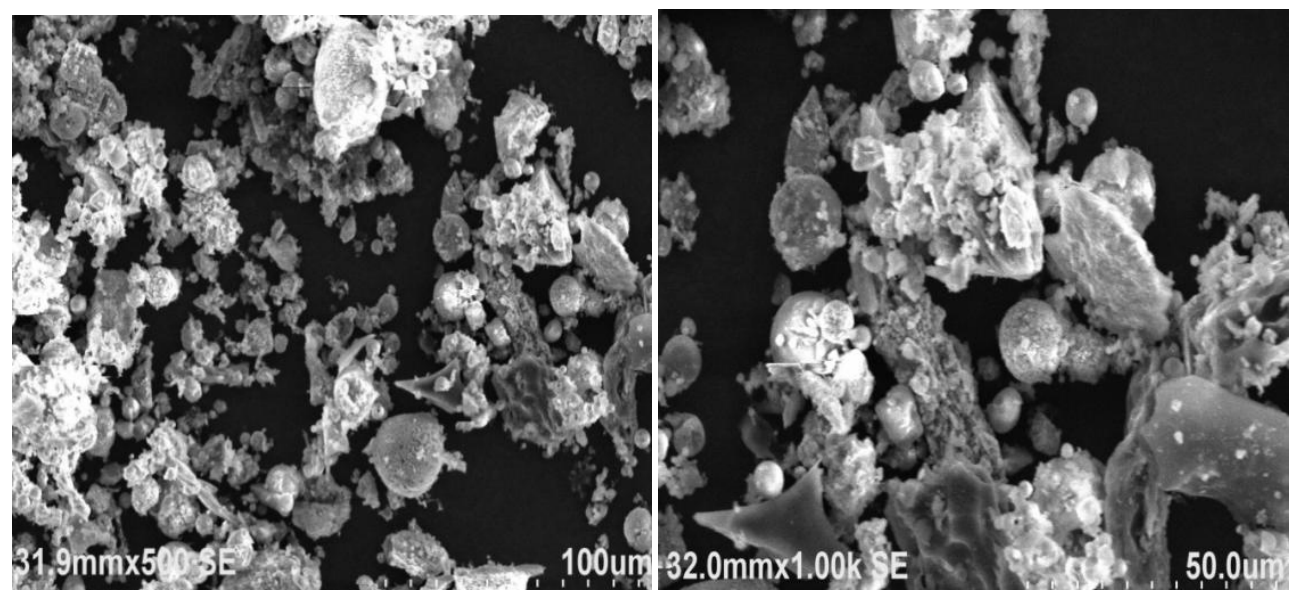

Fig 3. SEM images of Fly Ash - FA2

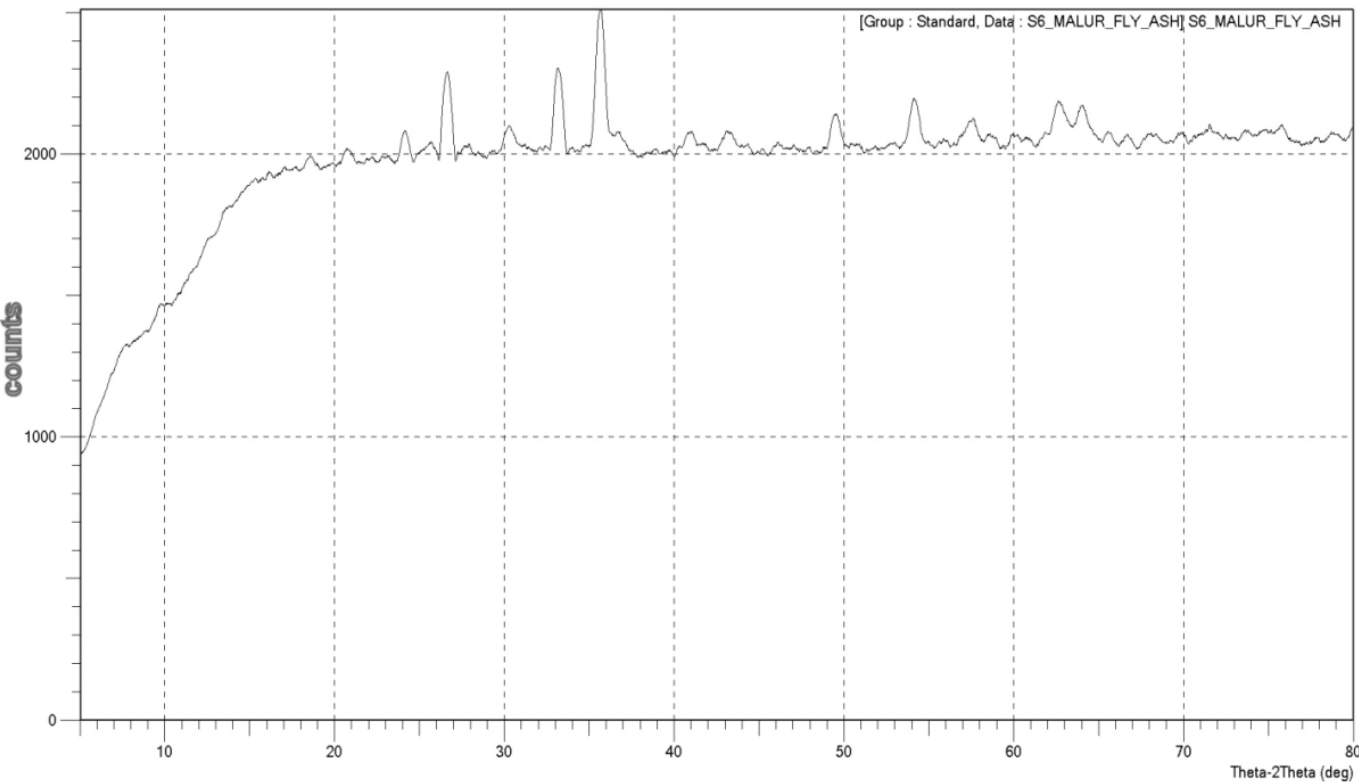

Fig 4. X- Ray Diffractogram of fly ash - FA2

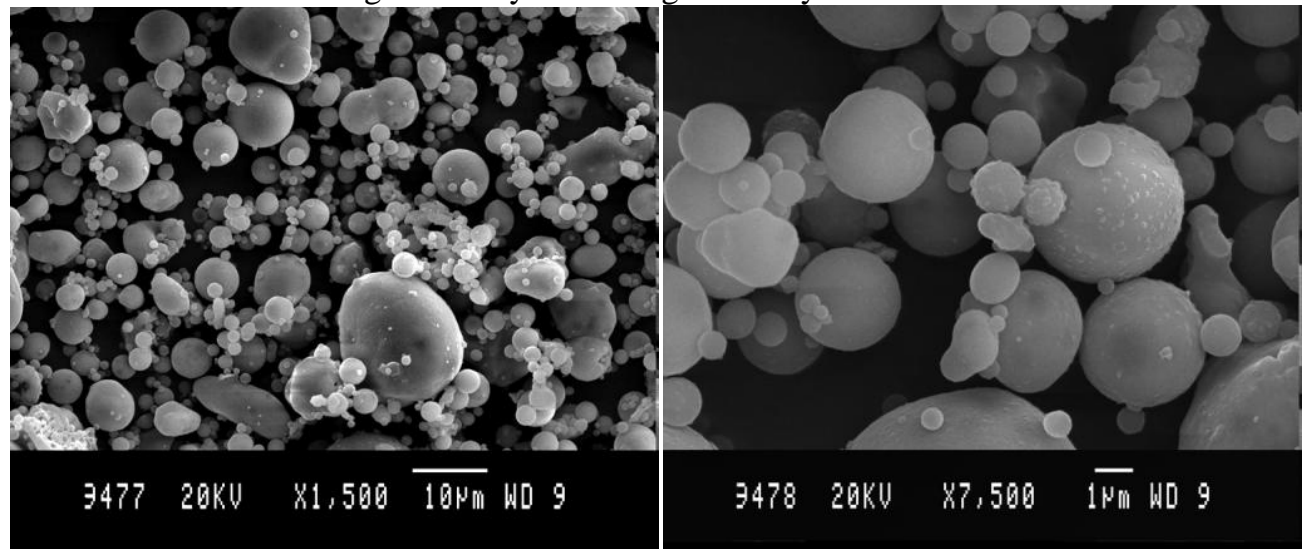

Magnification X1, 500 10um

Magnification X7, 500 1um

Fig 5. SEM images of Fly Ash - 


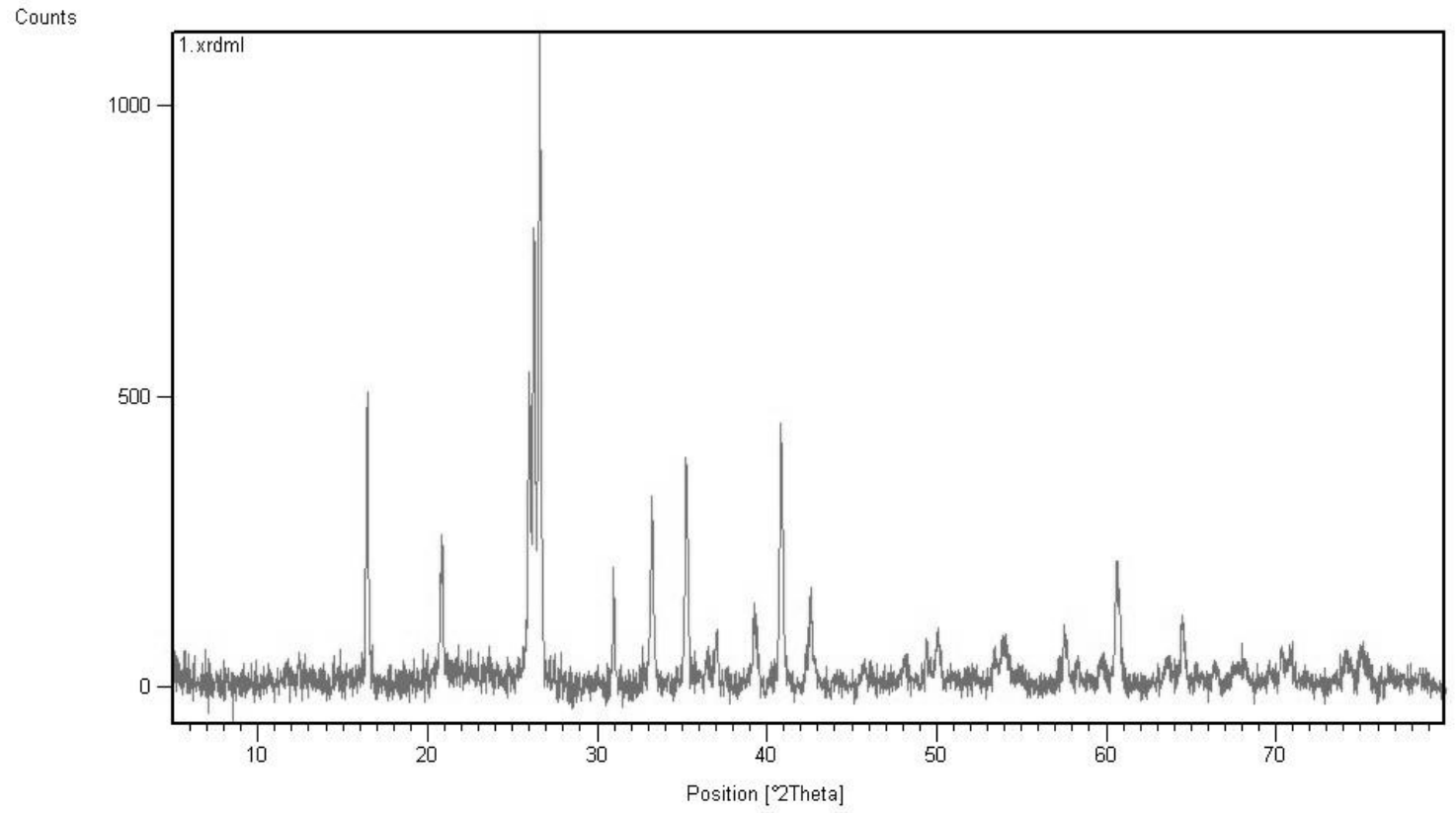

Fig 6.X- Ray Diffractogram of fly ash - FA3

A standard normal consistency test was conducted on FaL- required density. The compressed FaL-G cylinders were $\mathrm{G}$ paste and the water content for the normal consistency cured in wet cloth for 28days or till the age of testing was determined. The procedure adopted was the same whichever is earlier. The cylinders were tested for which is used for conventional cement. FaL-G paste compression at various ages. FaL-G paste was used to blocks were prepared from base materials fly ash, lime make low strength material. Flow and strength and gypsum. Tap water was used to mix the ingredients. characteristics were determined.Different proportions of The static compaction device was used to cast the FaL-G paste are tabulated in Table 6. The paste compressed cylinders of diameter $38 \mathrm{~mm}$ and height proportions used in standard consistency test along with $76 \mathrm{~mm}$, the volume being $86190 \mathrm{~mm}^{3}$. This process different types of lime are tabulated in Table7 compresses the wet mix into a specified size and to the

Table 6. Proportioning of FaL-G paste

\begin{tabular}{|c|c|c|c|c|c|}
\hline \multirow[t]{2}{*}{ SI no } & \multirow[t]{2}{*}{ Specimen ID } & \multicolumn{3}{|c|}{ Proportions } & \multirow{2}{*}{$\begin{array}{l}\text { Water/FaL-G } \\
\text { binder ratio }\end{array}$} \\
\hline & & Fly ash & Lime & Gypsum & \\
\hline 1 & FA1 & 45 & 45 & 10 & 0.2 \\
\hline 2 & FA1 & 50 & 40 & 10 & 0.2 \\
\hline 3 & FA1 & 55 & 55 & 10 & 0.2 \\
\hline 4 & FA1 & 60 & 30 & 10 & 0.2 \\
\hline 5 & FA2 & 60 & 30 & 10 & 0.2 \\
\hline 6 & FA2 & 70 & 20 & 10 & 0.2 \\
\hline 7 & FA2 & 75 & 15 & 10 & 0.2 \\
\hline 8 & FA3 & 50 & 40 & 10 & 0.2 \\
\hline 9 & FA3 & 55 & 35 & 10 & 0.2 \\
\hline
\end{tabular}

Table 7. FaL-G paste proportions used in standard consistency test

\begin{tabular}{|c|c|c|c|}
\hline Designation & Proportion of FaL-G & Fly ash type & Lime type \\
\hline $\mathrm{P} 1$ & $45: 45: 10$ & \multirow{4}{*}{$\begin{array}{c}\text { Un-processed } \\
\text { Raichur thermal power } \\
\text { plant } \\
\text { FA1 }\end{array}$} & \multirow{4}{*}{$\begin{array}{c}\text { Slaked lime } \\
\text { L1 }\end{array}$} \\
\hline $\mathrm{P} 2$ & $50: 40: 10$ & & \\
\hline P3 & $55: 35: 10$ & & \\
\hline $\mathrm{P} 4$ & $60: 30: 10$ & & \\
\hline P5 & $60: 30: 10$ & \multirow{3}{*}{$\begin{array}{c}\text { Un-processed } \\
\text { Malur sponge iron plant } \\
\text { FA2 }\end{array}$} & \multirow{5}{*}{$\begin{array}{c}\text { Ready Made } \\
\text { L2 }\end{array}$} \\
\hline P6 & $70: 20: 10$ & & \\
\hline P7 & $75: 15: 10$ & & \\
\hline P8 & $50: 40: 10$ & \multirow{2}{*}{$\begin{array}{c}\text { Processed } \\
\text { FA3 }\end{array}$} & \\
\hline P9 & $55: 35: 10$ & & \\
\hline
\end{tabular}

\section{Results and Discussion}


Standard consistency, Initial setting time and Final setting binder is almost same as cement sample. The initial and time of FaL-G paste are tabulated in Table $\mathbf{8}$ and final setting time is slightly more in slaked lime (L1)when represented in Fig 7. The normal consistency of FaL-G compared to ready made lime(L2).

Table 8 .Standard consistency and setting time of FaL-G paste

\begin{tabular}{|c|c|c|c|c|c|c|c|}
\hline \multirow{2}{*}{ Designation } & \multirow{2}{*}{$\begin{array}{c}\text { Proportion } \\
\text { of FaL-G }\end{array}$} & \multicolumn{2}{c|}{$\begin{array}{c}\text { Normal } \\
\text { consistency } \\
\text { \% }\end{array}$} & \multicolumn{2}{c|}{$\begin{array}{c}\text { Initial setting time } \\
\text { (hr:min) }\end{array}$} & \multicolumn{2}{c|}{$\begin{array}{c}\text { Final setting time } \\
\text { (hr:min) }\end{array}$} \\
\cline { 3 - 8 } & & L1 & L2 & L1 & L2 & L1 & L2 \\
\hline P1 & $45: 45: 10$ & 29 & 29 & $2: 40$ & $2: 15$ & $25: 10$ & $24: 30$ \\
\hline P2 & $50: 40: 10$ & 29 & 30 & $2: 50$ & $2: 20$ & $25: 15$ & $24: 35$ \\
\hline P3 & $55: 35: 10$ & 30 & 30 & $2: 55$ & $2: 30$ & $25: 20$ & $24: 40$ \\
\hline P4 & $60: 30: 10$ & 30 & 31 & $2: 55$ & $2: 35$ & $25: 25$ & $24: 45$ \\
\hline P5 & $60: 30: 10$ & - & 30 & - & $2: 05$ & - & $23: 35$ \\
\hline P6 & $70: 20: 10$ & - & 29 & - & $2: 05$ & - & $23: 40$ \\
\hline P7 & $75: 15: 10$ & - & 29 & - & $2: 15$ & - & $23: 55$ \\
\hline P8 & $50: 40: 10$ & - & 30 & - & $2: 05$ & - & $24: 10$ \\
\hline P9 & $55: 35: 10$ & - & 30 & - & $2: 15$ & - & $24: 15$ \\
\hline
\end{tabular}

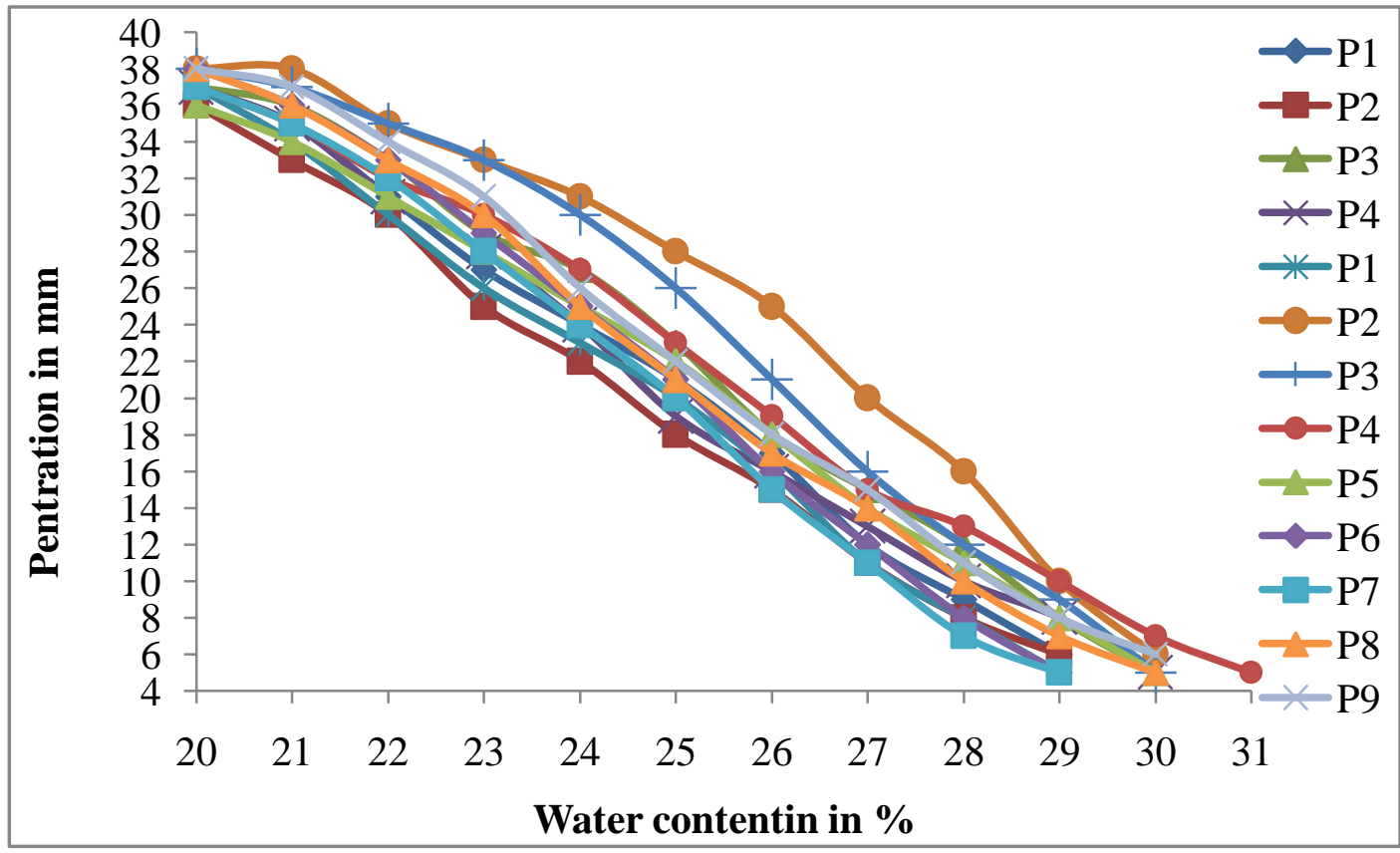

Fig 7.Standard consistency test for different paste proportions in FaL-G

COMPRESSIVE STRENGTH OF FaL-G PASTE

The results of compressive strength of FaL-G paste cylinders was determined at different ages are tabulated in Table 9.

It was noticed that FaL-G paste samples made with FA2 developed cracks for different water ratio $0.125,0.15$, higher than lime (L1) and airline cracks were observed 0.175 , and 0.2. Hence they were not considered for the FaL-G samples of fly ash (FA2). FA3 fly ash sample in strength development study. It was noticed that at constant FaL-G specimen has slight increase in strength than FA1 water-to-FaL-G ratio of 0.2 , as strength is higher for the samples

FaL-G samples made from FA1 and FA3 fly ash.
There was gradual increase in strength development for different age in days with different proportions of FaL-G with different fly ash (FA1and FA3) and with lime (L1andL2) as shown in Figs 8 and 9. It was noticed that strength development with use of lime (L2) was slightly 
International Advanced Research Journal in Science, Engineering and Technology

Vol. 2, Issue 3, March 2015

Table 9 Compressive strength of FaL-G paste at different age

\begin{tabular}{|c|c|c|c|c|c|c|c|c|c|}
\hline \multirow{2}{*}{ Designation } & \multirow{2}{*}{$\begin{array}{l}\text { Proportion } \\
\text { of FaL-G }\end{array}$} & \multicolumn{8}{|c|}{ Compressive Strength in Mpa } \\
\cline { 3 - 10 } & & \multicolumn{2}{|c|}{ 7days } & \multicolumn{2}{c|}{ 28 days } & \multicolumn{2}{|c|}{$\mathbf{5 6}$ days } & \multicolumn{2}{c|}{ 90 days } \\
\cline { 3 - 10 } & & L1 & L2 & L1 & L2 & L1 & L2 & L1 & L2 \\
\hline P1(FA1) & $45: 45: 10$ & 0.61 & 0.68 & 5.463 & 6.012 & 12.914 & 12.914 & 14.91 & 15.283 \\
\hline P2(FA1) & $50: 40: 10$ & 0.726 & 0.757 & 5.883 & 6.189 & 12.889 & 13.502 & 15.515 & 16.195 \\
\hline P3(FA1) & $55: 35: 10$ & 1.234 & 1.375 & 6.342 & 6.645 & 13.84 & 14.277 & 16.62 & 16.9 \\
\hline P4(FA1) & $60: 30: 10$ & 0.596 & 0.726 & 5.731 & 5.922 & 12.545 & 12.791 & 15.089 & 15.21 \\
\hline P8(FA3) & $50: 40: 10$ & - & 0.893 & - & 6.178 & - & 13.548 & - & 16.32 \\
\hline P9(FA3) & $55: 35: 10$ & - & 1.168 & - & 6.583 & - & 14.257 & - & 16.994 \\
\hline
\end{tabular}

NOTE: For P5,P6,P7 of FA2 Malur sponge iron plant fly device were observed with air line cracks on the surface of ash cylindrical specimens casted with static compaction the specime
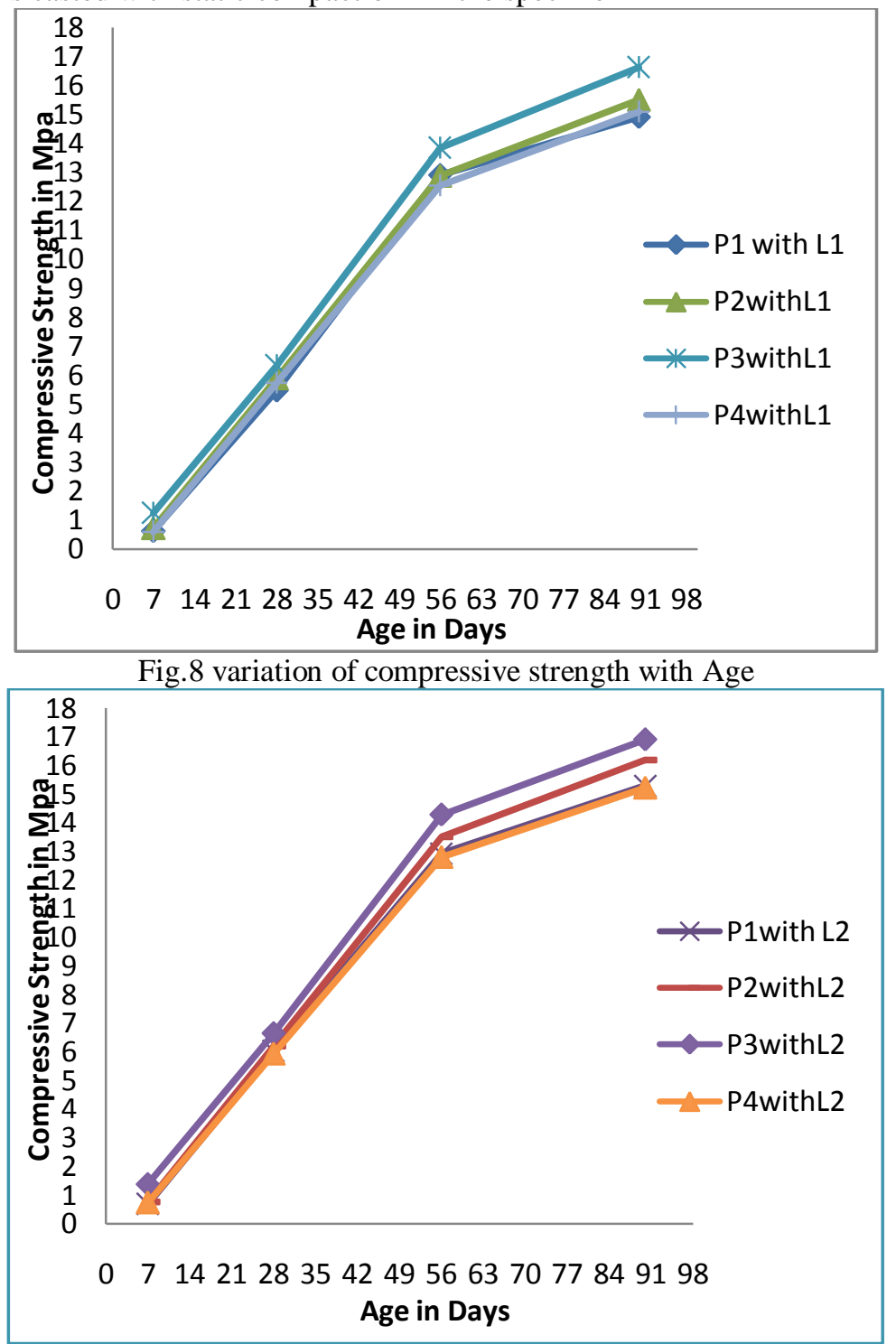

Fig 9 variation of compressive strength with Age

CONTROLLED LOW STRENGTH MATERIALS flow area) and Strength development is quite considerable (CLSM) implying that number of trials would be involved in

It can be seen in Table10 and $\mathbf{1 1}$ that in all the arriving suitable combinations. Since the strength cases of FaL-G the relative flow area increases with development is influenced by several factors such as type increase in water content. In turn the strength decreases of fly ash, lime, age and characteristics of materials with increase in fluid ratios. The range of RFA (relative 
International Advanced Research Journal in Science, Engineering and Technology

Vol. 2, Issue 3, March 2015

\begin{tabular}{|c|c|c|c|c|}
\hline Fly ash & \multicolumn{4}{|c|}{ FA1 } \\
\hline Lime & \multicolumn{4}{|c|}{$\mathbf{L 2}$} \\
\hline Designation & P1 & P2 & P3 & P4 \\
\hline Water/Binder ratio & \multicolumn{4}{|c|}{ spread in $\mathbf{m m}$} \\
\hline 34 & 11.23 & 10.32 & 12.52 & 11.62 \\
\hline 36 & 11.98 & 11.23 & 13.37 & 12.57 \\
\hline 38 & 12.68 & 12.12 & 14.15 & 13.67 \\
\hline 40 & 13.57 & 12.92 & 15.16 & 14.98 \\
\hline 42 & 14.86 & 14.3 & 16.22 & 15.82 \\
\hline 44 & 15.56 & 15.1 & 17.68 & 16.89 \\
\hline 46 & 15.99 & 15.85 & 18.68 & 18.54 \\
\hline 48 & 16.76 & 16.25 & & \\
\hline 50 & 17.5 & 16.68 & & \\
\hline 52 & 17.92 & 17 & & \\
\hline 54 & 18.56 & 17.5 & & \\
\hline 56 & & 18.5 & & \\
\hline
\end{tabular}

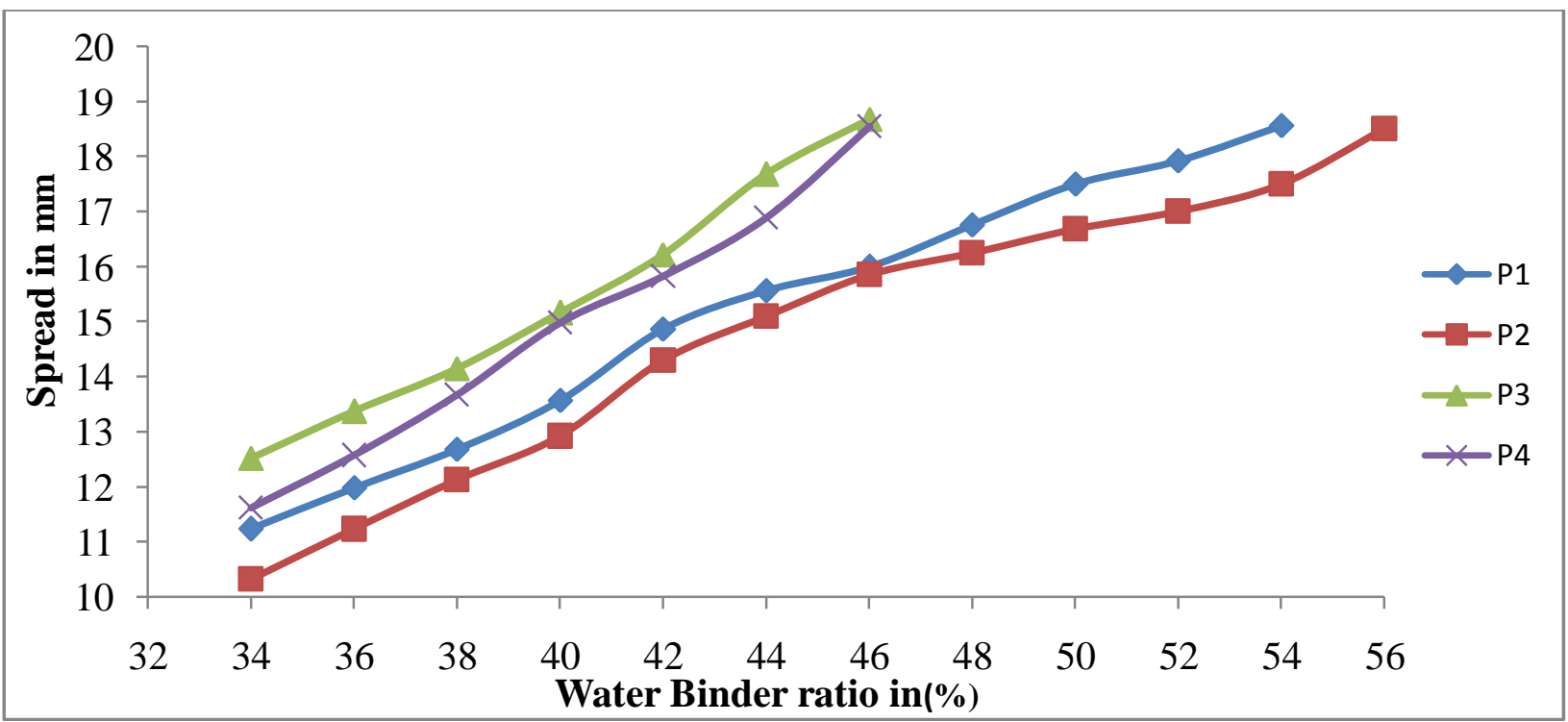

variation of spread with water content

Table 11 RFA and Average strength development values at 3, 7, 28 days for different proportions

\begin{tabular}{|c|c|c|c|c|c|}
\hline Designation & \multirow{2}{*}{$\begin{array}{c}\text { Water binder } \\
\text { ratio in \% }\end{array}$} & \multicolumn{4}{|c|}{ Normalized values } \\
\cline { 4 - 6 } & & \multirow{2}{*}{$\begin{array}{l}\text { RFA(relative } \\
\text { flow area) }\end{array}$} & $\mathbf{3}$ & $\mathbf{7}$ & $\mathbf{2 8}$ \\
\cline { 4 - 6 } & & 5.123 & 0.417 & 0.617 & 5.67 \\
\hline P1 & 54 & 5.091 & 0.481 & 0.689 & 6.012 \\
\hline P2 & 56 & 5.203 & 0.519 & 1.084 & 6.125 \\
\hline P3 & 46 & 5.112 & 0.435 & 0.665 & 5.512 \\
\hline P4 & 46 & & &
\end{tabular}

\section{CONCLUSIONS}

Based on the experimental works reported in the research, the following conclusion can be made.

$>\quad$ Standard consistency of FaL-G paste decreases with increase in lime content. 
$>\quad$ Strength gain of FaL-G composites is very slow compared to cement composites. Strength of FaL-G varies with percentage of fly ash content, lime content.

Micro structural studies show the densification of paste with the age.

FaL-G paste as CLSM results in good relative flow area (RFA) i.e a reflection of workability and the development of strength with age increases.

From the above studies and test results it can be concluded that non-cementitious paste can be produced from industrial waste materials like fly ash, lime and gypsum (FaL-G) that can be used as a building material in civil works.

\section{REFERENCES}

1. Bhanumathidas, N and Kalidas, N. (2002) "FaL-G: Hydraulic cement", Proc. Of National workshop on Alternative Building Methods. Department of Civil Engg. Indian Institute of Science. Bangalore: 2002, pp.17-23.

2. Singh.M. and M. Garg, (1997)," Durability of cementitious binder derived from industrial wastes", Mater Struct 30, pp. 607-612.

3. Sunil Kumar., (2002),"A perspective study on fly ash-limegypsum bricks and hollow blocks for low cost housing development", Construction and Building Materials, Volume 16, Issue 8, December 2002, 519-525.

4. ACI committee 211.1-91, (1994) "Standard practice for practice for selecting proportions for normal, heavy weight, and mass concrete", American Concrete Institute manual of concrete practice, part 1: Materials and General properties of concrete, pp38 ( Detroit, Michigan, 1994)

5. Abrams D. (1928) "Design of concrete mixtures", Bulletin No.1, ,Structural Materials Research Laboratory, Lewis Institute Chicago, p20-1918

6. Radhakrishna, "Analysis and Assessment of Compressive Strength in FaL-G Composites”, The Journal of Solid Waste Technology and Management, Volume 36, No.2, May 2010, pp 110-127.

7. SiamakBoudaghpour and AlirezaJadidi "Department of Environmental Engineering, K. N. Toosi, University of Technology, Iran. Islamic Azad University, Tehran Joyous, Iran "Accepted 09 July, 2009.

8. Amphora, V.M., "Making Concrete "Greener" with Fly Ash", in Concrete International, Vol.21, No. 5, May 1999, pp. 61-66.

9. Choudhary, R. (2006), "Evaluation of bituminous concrete mixes with industrial Wastes as filler", $\mathrm{Ph}$. D. dissertation, Department of Civil Engineering, Indian Institute of Technology, Rookie, India.

10. N Bhanumathidas and N Kalidas "Second International Symposium on Concrete Technology for Sustainable Development" (27 Feb-3 Mar, 2005; Hyderabad).

11. ACI committee 2322004 "use of fly ash in concrete". Farmington hills, Michigan, USA, American concrete institute: 41.

12. Spellings, R.; Martens G., Elsen J. "Supplementary cementitious materials". Reviews in Mineralogy and Geochemistry2012. 74: 211-278.

13. Palache C, H. Berman, and C. Frondel Dana's system of mineralogy, (7th edition), v. I, 503.

14. Bhanumathidas N \&KalidasN: Dual Role of Gypsum: Set Retarder and Strength Accelerator; Indian Concrete Journal, March 2004.

15. Bhanumathidas $\mathrm{N} \&$ Kalidas N: Portland FaL-G: A New Pozzolanic Blend; Civil Engineering \& Construction Review; May 1994.

16. MridulGarg , AakankshaPundir "Comprehensive study of fly ash binder developed with fly ash - alpha gypsum plaster - Portland cement" Construction and Building Materials 37 (2012) 758-765.

17. ArkamitraKar, Indrajit Ray, AvinashUnnikrishnan, Julio F. Davalos, "Prediction of Shrinkage of Concrete Containing Fly Ash and/or Silica Fume Using Composite Modeling" Earth and Space 2012: 732-743. 